\title{
Reduction of the phytate content of bran by leavening in bread and its effect on zinc absorption in man
}

\author{
BY BARBRO NÄVERT, BRITTMARIE SANDSTRÖM \\ Department of Clinical Nutrition, University of Göteborg, Annedalsklinikerna, \\ $S-41345$ Gothenburg, Sweden \\ AND $\AA$ KE CEDERBLAD \\ Department of Radiation Physics, University of Göteborg, Sahlgren's Hospital, \\ $S-41345$ Gothenburg, Sweden
}

(Received 20 December 1983 - Accepted 17 August 1984)

\footnotetext{
1. The effect of leavening of bread containing bran on the phytic acid content and on zinc absorption in man was studied.

2. Twenty breads with leavening times varying from 0 to $120 \mathrm{~h}$ were prepared. The breads contained $250 \mathrm{~g}$ wheat bran $/ \mathrm{kg}$ flour. The phytic acid content was determined after baking.

3. The phytic acid content of bread containing bran was reduced to about $40 \%$ after $2 \mathrm{~h}$ of leavening and to $15 \%$ after $2 \mathrm{~d}$. No further decrease was observed.

4. Zn absorption from single meals was determined using a radioisotope technique. Forty-two students volunteered for these studies. They were served a breakfast of milk, butter, bread and 10,16 or $30 \mathrm{~g}$ bran served either raw or baked into the bread with fermentation times of $15 \mathrm{~min}, 45 \mathrm{~min}, 3 \mathrm{~h}$ or $16 \mathrm{~h}$. One meal contained no bran, but phytate and $\mathrm{Zn}$ were added in amounts equivalent to the content of $10 \mathrm{~g}$ bran.

5. The amount and percentage of $\mathrm{Zn}$ absorbed increased at each bran level as fermentation was prolonged. The percentage of $\mathrm{Zn}$ absorbed was reduced by increased bran content in the meal.

6. It is concluded that the fermentation of bread containing bran reduces the phytic acid content and increases $\mathrm{Zn}$ absorption from such bread. This may be of importance to people subjected to diets with a high cereal content, especially in combination with a low animal-protein intake.
}

Dietary fibre is of great interest in human nutrition and an increased intake is recommended in many countries. Wheat bran and wholemeal bread are good sources of dietary fibre but have been associated with poor bioavailability of zinc and other minerals (McCance \& Widdowson, 1942; Reinhold et al. 1976a; Sandberg et al. 1982). In the case of $\mathrm{Zn}$ this is thought to be due to the high content of phytate in these products (Davies et al. 1977; Davies, 1978 ) or to the high fibre content (Reinhold et al. 1974, 1975). One way to reduce the phytic acid content is through fermentation. The aim of the present study was to find out what changes occur in the phytic acid content of bran during bread-making with varying leavening times and what effect the leavening time of bread containing bran has on $\mathrm{Zn}$ absorption.

\section{METHODS}

\section{Bread for fermentation study}

A dough was made from commercially available wheat bran, yeast and water. The dough was left to leaven at room temperature. Twenty different leavening times between 0 and $120 \mathrm{~h}$ were used, whereafter wheat flour, salt and sugar were added. A loaf was prepared and allowed to rise for another $0.5 \mathrm{~h}$. It was then baked for $12 \mathrm{~min}$ at $225^{\circ}$. The dough contained $250 \mathrm{~g}$ bran $/ \mathrm{kg}$ flour. 
Table 1. Zinc, iron, magnesium and phytic acid contents of and $Z n$ absorption from meals containing bran, bread, butter and milk when the bran was either served raw or baked in bread with different fermentation times

\begin{tabular}{|c|c|c|c|c|c|c|c|c|c|c|c|}
\hline \multirow{3}{*}{$\begin{array}{c}\text { Meal } \\
\text { no. }\end{array}$} & \multirow[b]{3}{*}{$n$} & \multirow{3}{*}{$\begin{array}{c}\text { Amount } \\
\text { of bran } \\
\text { (g) }\end{array}$} & \multirow{3}{*}{$\begin{array}{c}\text { Fermen- } \\
\text { tation } \\
\text { time }\end{array}$} & \multirow{3}{*}{$\underset{(\mu \mathrm{mol})}{\mathrm{Zn}}$} & \multirow{3}{*}{$\underset{(\mu \mathrm{mol})}{\mathrm{Fe}}$} & \multirow{3}{*}{$\underset{(\mathrm{mmol})}{\mathbf{M g}}$} & \multirow{3}{*}{$\begin{array}{c}\text { Phytic } \\
\text { acid } \\
(\mu \mathrm{mol})\end{array}$} & \multirow{3}{*}{$\begin{array}{l}\text { Molar } \\
\text { ratio, } \\
\text { phytic } \\
\text { acid: } \mathrm{Zn}\end{array}$} & \multicolumn{3}{|c|}{ Zn absorption } \\
\hline & & & & & & & & & \multicolumn{2}{|c|}{$(\%)$} & $(\mu \mathrm{mol})$ \\
\hline & & & & & & & & & Mean & $\mathbf{S E}$ & Mean SE \\
\hline 1 & 8 & 10 & - & 29 & 73 & $3 \cdot 0$ & 500 & 17 & $9 \cdot 6^{a, c}$ & 0.5 & $2 \cdot 7^{\mathrm{a}, \mathrm{e}} 0 \cdot 1$ \\
\hline 2 & 8 & 10 & $45 \mathrm{~min}$ & 27 & 77 & $2 \cdot 8$ & 420 & 16 & $11 \cdot 9^{b, c}$ & 0.9 & $3 \cdot 2^{\mathrm{a}, \mathrm{c}} 0.2$ \\
\hline 3 & 8 & 10 & $3 \mathrm{~h}$ & 31 & 72 & $2 \cdot 8$ & 240 & 8 & $14 \cdot 7^{b}$ & $2 \cdot 1$ & $4.6^{\mathrm{b}, \mathrm{d}} 0.6$ \\
\hline 4 & 9 & 10 & $16 \mathrm{~h}$ & 27 & 75 & $3 \cdot 0$ & 110 & 4 & $19 \cdot 8^{d}$ & 1.6 & $5.4^{\mathrm{d}} \quad 0.4^{2}$ \\
\hline 5 & 9 & 16 & $\ldots$ & 40 & 83 & 4.0 & 790 & 20 & $5 \cdot 9^{\mathrm{e}}$ & 0.5 & $2 \cdot 3^{a} \quad 0.2$ \\
\hline 6 & 8 & 30 & $15 \mathrm{~min}$ & 59 & 102 & 6.0 & 1370 & 23 & $46^{8}$ & 0.8 & $2 \cdot 7^{a, c} 0.5$ \\
\hline 7 & 8 & 30 & $16 \mathrm{~h}$ & 56 & 98 & $6 \cdot 3$ & 520 & 9 & $6 \cdot 6^{a, e}$ & $1 \cdot 1$ & $3.7^{\mathrm{b}, \mathrm{c}} 0.6$ \\
\hline 8 & 8 & 0 & $45 \mathrm{~min}$ & $31^{*}$ & 36 & $1 \cdot 2$ & 490 & 16 & $6 \cdot 1^{\mathrm{a}, \mathrm{e}}$ & 0.8 & $\begin{array}{ll}1.9^{a} & 0.2\end{array}$ \\
\hline
\end{tabular}

a,b,c,d,e Values for meals with the same superscript letters were not significantly different: $P<0 \cdot 05$.

* Enriched with zinc sulphate.

\section{Subjects for Zn absorption study}

Forty-two students (seventeen males, twenty-five females) between 20 and 52 years of age (median 23 years) volunteered for the study. Twenty-four subjects participated twice. They were all apparently healthy, non-pregnant, without known gastrointestinal disorders and had normal serum Zn levels of $11 \cdot 2-15 \cdot 4$ (mean 12.9) $\mu$ mol/1. The subjects were given written and oral information about the aim and procedure of the study.

\section{Meals for Zn absorption study}

The test meals for the $\mathrm{Zn}$ absorption study consisted of $200 \mathrm{~g}$ fermented milk, $10 \mathrm{~g}$ butter, $200 \mathrm{~g}$ deionized water, two rolls containing $20 \mathrm{~g}$ wheat flour each and 10,16 or $30 \mathrm{~g}$ wheat bran served either raw or baked in the bread with fermentation times of $15 \mathrm{~min}, 45 \mathrm{~min}$, $3 \mathrm{~h}$ or $16 \mathrm{~h}$ (see Table 1). As it was difficult to eat $30 \mathrm{~g}$ bran in the raw state, it was instead baked in bread with the shortest possible leavening time $(15 \mathrm{~min})$. The breads were baked in a similar way to those used in the fermentation study. One meal (no. 8) contained no bran. Instead, phytic acid and $\mathrm{Zn}$ were added to the dough in amounts equivalent to the content of $10 \mathrm{~g}$ bran. Thus, $520 \mu \mathrm{mol}$ phytate as sodium phytate (BDH Chemicals Ltd, Poole, Dorset) and $13 \mu \mathrm{mol} \mathrm{Zn}$ as $\mathrm{ZnSO}_{4} .7 \mathrm{H}_{2} \mathrm{O}$ were added per $40 \mathrm{~g}$ flour. Each meal was extrinsically labelled with $0.02 \mathrm{MBq}{ }^{65} \mathrm{Zn}$ by adding almost carrier-free ${ }^{65} \mathrm{ZnCl}_{2}$ solution $(0.8 \mathrm{MBq} / \mu \mathrm{mol} \mathrm{Zn}$; Amersham International plc, Amersham, Bucks) to the bran when served raw or to the dough when the bran was baked in bread. In the meal without bran (no. 8) the ${ }^{65} \mathrm{ZnCl}_{2}$ was added to the dough.

\section{Zn absorption measurements}

$\mathrm{Zn}$ absorption was determined using the radioisotope technique described by Arvidsson $e t$ al. (1978). Each extrinsically labelled meal was measured in a whole-body counter. The subjects were randomly allocated to the meals that were served after an overnight fast and measurement of the subject's background radioactivity. Neither food nor drink were allowed for $3 \mathrm{~h}$ after intake of the meal. The whole-body retention of the radioisotope was 
measured 10-14 d after intake of the meal to allow excretion of the unabsorbed fraction. Allowance was made for the excretion of initially absorbed isotope during the time between intake and retention measurement based on the mean rate of excretion of an intravenously administered dose of ${ }^{65} \mathrm{Zn}$ in a similar group of subjects (Arvidsson et al. 1978). When the subjects participated the second time, allowance was also made for the excretion of the residual radioactivity from the first meal.

\section{Food analyses}

Portions of the food served were freeze-dried, homogenized and analysed for their contents of $\mathrm{Zn}$, calcium, iron, magnesium, phosphorus, nitrogen, phytic acid and dietary fibre. $\mathrm{Zn}$ and $\mathrm{Fe}$ were determined by atomic absorption spectrophotometry (Perkin Elmer Model 360) after dry-ashing samples at $450^{\circ}$. $\mathrm{Ca}$ and $\mathrm{Mg}$ analyses were also performed by atomic absorption spectrophotometry after addition of lanthanum oxide to the digest obtained after wet-ashing in sulphuric acid and hydrogen peroxide. The same digest was used to determine $\mathbf{P}$ by the Fiske-Subbarow method (Fiske \& Subbarow, 1925). Reference standards for $\mathrm{Zn}, \mathrm{Fe}, \mathrm{Ca}$ and $\mathrm{Mg}$ were prepared from Titrisol (Mercks). Reference standard materials with concentrations representative of those found in the diet samples were run simultaneously and fell within the certified range (Orchard Leaves SRM 1571 and Bovine Liver SRM 1577 (a), National Bureau of Standards, USA). N analysis was performed by a micro-Kjeldahl technique (Technicon AutoAnalyzer). The $\mathrm{N}$ values were converted to protein values by the factor 6.38 for milk and 5.70 for bran and bread. Phytic acid was determined by Davies \& Reid's (1979) modification of the procedure of Holt (1955). In cereals, neutral polysaccharide constituents and lignin are the major components of "dietary fibre'. These fibre fractions were measured according to method B of Theander \& Aman (1981).

\section{Statistical methods}

Results were analysed by analysis of variance and means were compared by the use of Duncan's multiple range test (SAS Inst. Inc., Carry, North Carolina) at the $5 \%$ level of probability.

\section{Ethical considerations}

This project was approved by the Research Ethical Committee and the Isotope Committee at Sahlgren's Hospital.

\section{RESULTS}

\section{Leavening of bread containing bran}

The effect of leavening time on phytic acid in bread containing bran is shown in Fig. 1. A substantial reduction of about $60 \%$ was observed after only $2 \mathrm{~h}$ of leavening. After $2 \mathrm{~d}$ the reduction was $80-85 \%$ and there was no further decrease. However, the breads left to rise for that period of time had a strong acid taste, while those with shorter leavening times were quite palatable.

\section{Zn absorption study}

$\mathrm{Zn}, \mathrm{Fe}, \mathrm{Mg}$ and phytic acid contents of the meals are shown in Table 1. The $\mathrm{Zn}$ content was $27-59 \mu \mathrm{mol}$, Fe 36-102 $\mu \mathrm{mol}$ and $\mathrm{Mg} \mathrm{1} \cdot 2-6 \cdot 3 \mathrm{mmol}$, depending on the amount of bran in the meal. A short leavening time $(45 \mathrm{~min}$ ) for bread containing $10 \mathrm{~g}$ bran reduced the phytic acid content from 500 to $420 \mu \mathrm{mol}$ while prolonged leavening $(16 \mathrm{~h})$ reduced it to $110 \mu \mathrm{mol}$. Bread with $30 \mathrm{~g}$ bran and a leavening time of only $15 \mathrm{~min}$ contained $1370 \mu \mathrm{mol}$ phytic acid. This was reduced to $520 \mu \mathrm{mol}$ after $16 \mathrm{~h}$ of leavening. The molar ratios, phytic acid: $\mathrm{Zn}$ obtained were thus between 4 and 23 . The Ca content was similar in all meals $(6-7 \mathrm{mmol})$ and was largely supplied by the milk. The milk also contributed about half the 


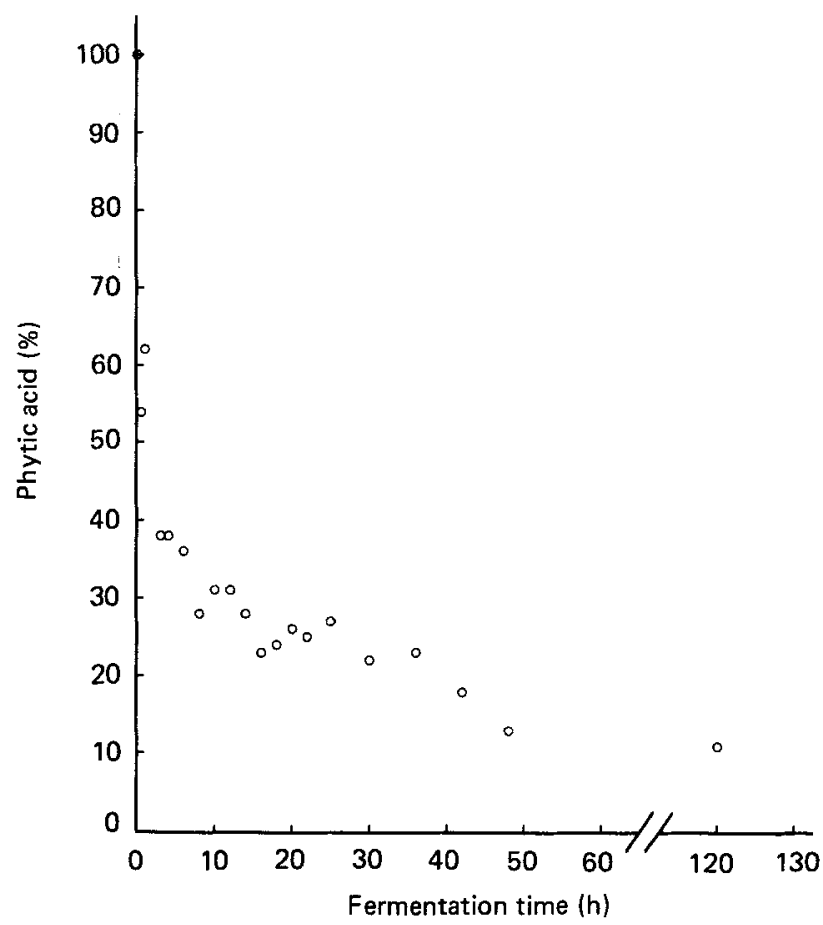

Fig. 1. The reduction through leavening of phytic acid in bread containing bran. Values are expressed as percent of phytic acid content before leavening.

protein content of $12 \mathrm{~g}$. The $P$ content was 11,14 or $20 \mathrm{mmol}$ in the meals containing 10 , 16 or $30 \mathrm{~g}$ bran respectively, while meal no. 8 without bran contained $11 \mathrm{mmol} \mathrm{P}$. The sum of neutral polysaccharide and lignin contents was 5,8 or $14 \mathrm{~g}$ for the 10,16 and $30 \mathrm{~g}$ bran meals respectively, and $1 \mathrm{~g}$ in the meal without bran. No change either in amount or composition of 'dietary fibre' was found after baking.

The percentage and amount of $\mathrm{Zn}$ absorbed from each meal are shown in Table 1. Both the actual amount and percentage of $\mathrm{Zn}$ absorbed from the meals containing 10 and $30 \mathrm{~g}$ bran increased when the fermentation time was increased. Adding $10 \mathrm{~g}$ bran to bread and leavening for $16 \mathrm{~h}$ doubled the amount of $\mathrm{Zn}$ absorbed compared with serving the bran raw or baked in bread fermented for only $45 \mathrm{~min}$. The percentage of $\mathrm{Zn}$ absorbed was reduced by increased bran content in the meal. This was to some extent compensated for by the high $\mathrm{Zn}$ content in bran. The amount of $\mathrm{Zn}$ absorbed, however, was significantly higher $(P<0.05)$ from bread containing $10 \mathrm{~g}$ bran and fermented for $16 \mathrm{~h}$ (meal no. 4) than from the corresponding bread containing $30 \mathrm{~g}$ bran (meal no. 7). The amount of $\mathrm{Zn}$ absorbed from the bread with added sodium phytate (meal no. 8) was not significantly different from that from raw bran (meal no. 1) or from bread with bran containing the same amount of phytic acid (meal no. 2).

\section{DISCUSSION}

Opinions differ as to whether phytic acid or 'dietary fibre' is the cause of the negative effect on $\mathrm{Zn}$ availability observed from foodstuffs rich in fibre. Reinhold and co-workers (Reinhold et al. 1973a,b) suggested from studies on humans that phytic acid may be the 


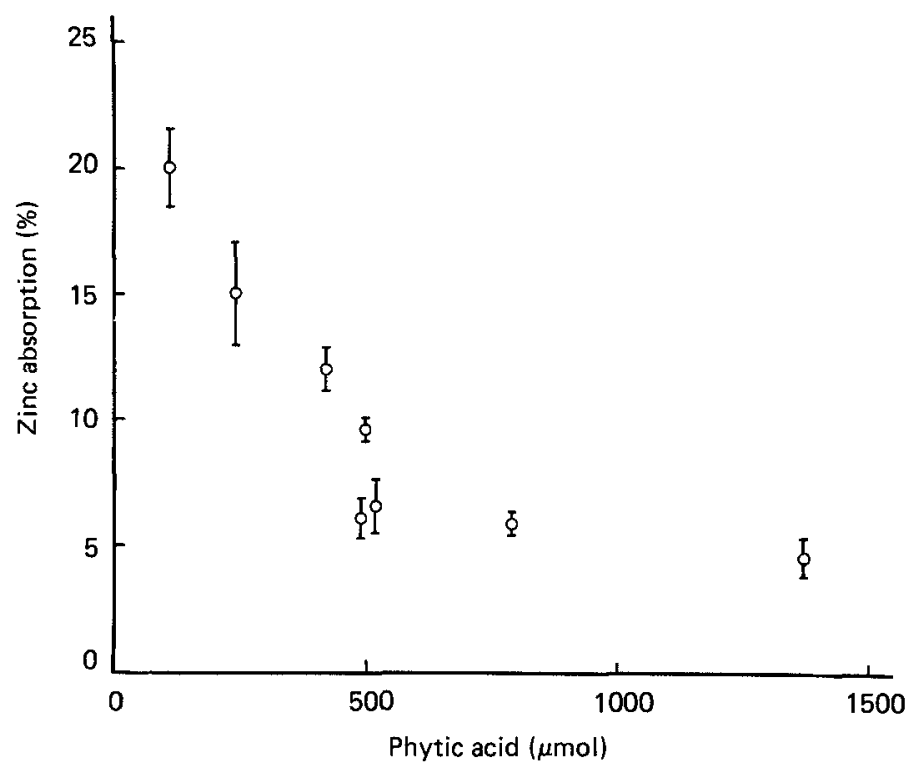

Fig. 2. Zinc absorption ( $\%$ ) from meals based on cereals in relation to the phytic acid content ( $\mu$ mol) of the meal. Points are mean values with their standard errors represented by vertical bars.

main inhibitory agent but later (Reinhold et al. 1975, 1976b) changed their view to suggest fibre as the main cause. Their later studies, however, are mainly in vitro work. Davies et al. (1977) found a decreased $\mathrm{Zn}$ availability in rats when phytic acid was added to the diet and an increased availability from bran with reduced phytate content. Caprez \& FairweatherTait (1982) found no change in $\mathrm{Zn}$ absorption in the rat when the phytic acid content of bran was reduced to two-thirds of the original value by heat treatment but observed an improved $\mathrm{Zn}$ absorption when all phytate was removed from the diet through treatment with phytase. In a $3 \times 24 \mathrm{~d}$ balance study of six human subjects on diets that included $200 \mathrm{~g}$ white, brown or wholemeal bread/d, and with a constant mineral and phytic acid content, Andersson et al. (1983) found no change in $\mathrm{Zn}, \mathrm{Fe}$ or Ca balance, indicating that fibre components other than phytic acid have little effect on mineral availability.

The results obtained in the present study strongly support the view that phytic acid is one of the determinants of $\mathrm{Zn}$ availability from cereal-based meals (Fig. 2). By the use of fermentation to reduce the phytic acid content the fibre content of the bread was not changed. It is, however, possible that some qualitative changes of the fibre or other components of the bran occurred in the dough during fermentation which favoured the absorption of $\mathrm{Zn}$. Our results from the meal with white bread and added sodium phytate also indicate that phytic acid may act as a $\mathrm{Zn}$-depressing agent in human diets. In earlier studies of similar meals with white bread, 13-38\% absorption of $\mathrm{Zn}$ have been observed (Arvidsson et al. 1978; Sandström et al. 1980) while in the present study only $6 \%$ were absorbed from the meal with white bread and sodium phytate.

The molar ratio, phytic acid: $\mathrm{Zn}$ has been suggested to be an important determinant of $\mathrm{Zn}$ bioavailability from human diets (Oberleas \& Harland, 1981). In studies on rats, high molar ratios have been shown to reduce significantly the availability of $\mathrm{Zn}$. Lo et al. (1981) found a reduced retention of $\mathrm{Zn}$ when the ratio was 12.5 or higher. Morris \& Ellis (1980) found that the maximum ratio for unchanged growth rate of rats was greatly influenced by the dietary $\mathrm{Ca}$ level and, to a lesser extent, by the total $\mathrm{Zn}$ intake; thus a ratio of 12 or more depressed growth when the Ca content was $7.5 \mathrm{~g} / \mathrm{kg}$ diet while it needed only a 
ratio of 6 to depress growth when the Ca content was $17.5 \mathrm{~g} / \mathrm{kg}$ diet. In a later study, Morris \& Ellis (1981) reported that breakfast cereals with phytate: $\mathrm{Zn}$ molar ratios above 15 depressed growth in rats. Davies \& Olpin (1979) found reduced plasma $\mathrm{Zn}$ in rats given a diet with a ratio of 10 or more, and reduced growth rate and hair $\mathrm{Zn}$ concentrations following a diet with a ratio of 15 or above. The results from the present study support the idea that the molar ratio, phytic acid: $\mathrm{Zn}$ can be used as a determinant of $\mathrm{Zn}$ bioavailability from cereal-based meals to humans. When the ratio was decreased by the fermentation of $10 \mathrm{~g}$ bran from 17 to 8 in meal no. 3, $\mathrm{Zn}$ absorption was similar to that observed earlier from $\mathrm{Zn}$-enriched white bread (Arvidsson et al. 1978), while a reduction of the ratio from 23 to 9 in the meal with $30 \mathrm{~g}$ bran (meal no. 7) resulted in an increased, yet still low, amount of $\mathrm{Zn}$ absorbed.

In the present study, fermented milk was included in meals to make the meals complete and to keep the $\mathrm{Ca}$ content relatively high. In animal studies the $\mathrm{Ca}$ content of the diet has been found to be of importance for the effect of phytic acid on $\mathrm{Zn}$ availability (O'Dell, 1969; Davies \& Olpin, 1979; Morris \& Ellis, 1980). Wise (1983) has suggested that at a molar ratio, $\mathrm{Ca}$ :phytate of $6: 1$ or more, all phytate is precipitated in the small intestine and the trace metals present are bound to this complex. He suggests that the fate of the trace elements then depends on the level of dietary amino acids which desorb trace minerals from the complex and facilitate absorption. In the present study the ratio, $\mathrm{Ca}$ :phytic acid was 6 or more for all meals except meal no. 6 , which had a ratio of 5 , with the Ca mainly supplied by milk which also supplied about half the protein of the meal. A similar level of $\mathrm{Zn}$ absorption was observed from the meal containing bread with $10 \mathrm{~g}$ bran, fermented for only a short time, as previously observed from a wholemeal bread with similar phytic acid content but served with water (Sandström et al. 1980). The possible negative effect of Ca in meals rich in phytic acid is thus overcome by the increase in protein content if $\mathrm{Ca}$ is supplied by milk. Citrate has been identified as a Zn-binding compound in milk (Lönnerdal et al. 1980). However, in $\mathrm{Zn}$-absorption studies on humans using the same radioisotope technique as that used in the present study, no effect on $\mathrm{Zn}$ absorption was observed when citrate was added to human milk or infant formulas (Sandström et al. 1983 b). Additional milk or other animal protein has been found to increase $\mathrm{Zn}$ absorption further (Sandström et al. 1980) and might be desirable in meals with a high bran content.

The observed low $\mathrm{Zn}$ absorption, even after fermentation, from meals containing $30 \mathrm{~g}$ bran may be due to the high fibre content. This was to some extent compensated for by a high Zn content in the meal, in accordance with earlier observations (Sandström \& Cederblad, 1980), but the actual amount of $\mathrm{Zn}$ absorbed was still quite low. Reduced Fe and $\mathrm{Ca}$ levels in blood have been reported after intake of large amounts of bran, i.e. 36-100 $\mathrm{g} / \mathrm{d}$ (Heaton \& Pomare, 1974; Jenkins et al. 1975), while the addition of $20 \mathrm{~g} / \mathrm{d}$ to a nutritionally adequate diet showed no negative effects on mineral status (Sandström et al, $1983 a$ ). While a high fibre intake in the form of wholemeal bread also supplies protein, an excessively high bran intake might create an unbalanced diet.

The substantial improvement in $\mathrm{Zn}$ absorption obtained by prolonged leavening of bread containing moderate amounts of bran may be of practical importance to cereal-based diets with a low animal-protein content. In most western-world diets the phytic acid content is low and the intake of cereal fibre-rich products to an otherwise balanced diet is not thought to have any harmful effect on $\mathrm{Zn}$ availability.

The authors thank Ms Annette Almgren for excellent technical assistance and Ms Helena Göransson for valuable help in making the breads for the study. This work was supported by grants from the National Swedish Board for Technical Development. 


\section{REFERENCES}

Andersson, H., Nävert, B., Bingham, S. A., Englyst, H. N. \& Cummings, J. H. (1983). British Journal of Nutrition 50, 503-510.

Arvidsson, B., Cederblad, Å., Björn-Rasmussen, E. \& Sandström, B. (1978). International Journal of Nuclear Medicine and Biology 5, 104-109.

Caprez, A. \& Fairweather-Tait, S. J. (1982). British Journal of Nutrition 48, 467-475.

Davies, N. T. (1978). Journal of Plant Foods 3, 113-121.

Davies, N. T., Hristic, V. \& Flett, A. A. (1977). Nutrition Reports International 15, 207-214.

Davies, N. T. \& Olpin, S. E. (1979). British Journal of Nutrition 41, 591-603.

Davies, N. T. \& Reid, H. (1979). British Journal of Nutrition 41, 579-589.

Fiske, C. H. \& Subbarow, Y. (1925). Journal of Biological Chemistry 66, 375-400.

Heaton, K. W. \& Pomare, E. W. (1974). Lancet i, 49-50.

Holt, P. (1955). Journal of the Science of Food and Agriculture 6, 136-142.

Jenkins, D. J. A., Hill, M. S. \& Cummings, J. H. (1975). American Journal of Clinical Nutrition 28, $1408-1411$.

Lo, G. S., Settle, S. L., Steinke, F. H. \& Hopkins, D. T. (1981). Journal of Nutrition 111, 2223-2235.

Lönnerdal, B., Stanislowski, A. G. \& Hurley, L. S. (1980). Journal of Inorganic Biochemistry 12, 71-78.

McCance, R. A. \& Widdowson, E. M. (1942). Journal of Physiology 101, 44-85.

Morris, E. R. \& Ellis, R. (1980). Journal of Nutrition 110, 1037-1045.

Morris, E. R. \& Ellis, R. (1981). Cereal Chemistry 58, 363-366.

Oberleas, D. \& Harland, B. F. (1981). Journal of the American Dietetic Association 79, 433-436.

O'Dell, B. L. (1969). American Journal of Clinical Nutrition 22, 1315-1322.

Reinhold, J. G., Faradji, B., Abadi, P. \& Ismail-Beigi, F. (1976a). Journal of Nutrition 106, 493-503.

Reinhold, J. G., Faradji, B., Abadi, P. \& Ismail-Beigi, F. (1976 b). In Trace Elements in Human Health and Disease, vol. 1, pp. 163-180 [A. S. Prasad and D. Oberleas, editors]. London: Academic Press.

Reinhold, J. G., Hedayati, H., Lahimgarzadeh, A. \& Nasr, K. (1973a). Ecology of Food and Nutrition 2, $157-162$.

Reinhold, J. G., Ismail-Beigi, F. \& Faradji, B. (1975). Nutrition Reports International 12, 75-85.

Reinhold, J. G., Lahimgarzadeh, A., Nasr, K. \& Hedayati, H. (1973b). Lancet i, 283-288.

Reinhold, J. G., Parsa, A., Karimian, N., Hammick, J. W. \& Ismail-Beigi, F. (1974). Journal of Nutrition 104, 976-982.

Sandberg, A.-S., Hasselblad, C. \& Hasselblad, K. (1982). British Journal of Nutrition 48, 185-191.

Sandström, B., Andersson, H., Bosaéus, I., Falkheden, T., Göransson, H. \& Melkersson, M. (1983a). Human Nutrition: Clinical Nutrition 37C, 295-300.

Sandström, B., Arvidsson, B., Cederblad, Å. \& Björn-Rasmussen, E. (1980). American Journal of Clinical Nutrition 33, 739-745.

Sandström, B. \& Cederblad, A. (1980). American Journal of Clinical Nutrition 33, 1778-1783.

Sandström, B., Cederblad, A. \& Lönnerdal, B. (1983 b). American Journal of Diseases of Children 137, 726-729.

Theander, O. \& Aman, P. (1981). In The Analysis of Dietary Fiber in Food. Basic and Clinical Nutrition, vol. 3 , pp. 51-70 [W. P. T. James and O. Theander, editors]. New York \& Basel: Marcel Dekker Inc.

Wise, A. (1983). Nutrition Abstracts and Reviews in Clinical Nutrition A 53, 791-806. 